\title{
New Forestry Politics of Mangkunegara VII, 1911-1942
}

\author{
Nina Witasari ${ }^{1}$ \\ \{ninawitasari@mail.unnes.ac.id ${ }^{1}$ \} \\ Universitas Negeri Semarang, Indonesia ${ }^{1}$
}

\begin{abstract}
Forest management in the Mangkunegaran (MN) area is largely through two periods, the management period by Wreksa Pandaya and the management period of Wanamarta. Kemantren Wreksa Pandaya has been operating at the time of MN IV, the task was more to fulfill the interests of the palace needs for timber and other forest products. While the maintenance task has become a result of economic expansion which has led to forest degradation and environmental damage. Over time, economic changes and political conditions both globally and locally, forest management has also undergone a fairly fundamental change. The exploitation of the Mangkunegara IV forest is like two knives for its prejudice, on the one hand it brings economic prosperity but on the other hand brings ecological damage. Mangkunegara VII makes several forestry regulations. These regulations generally limit the access of people living around the forest, to the Mangkunegaran forest. Problems then arise when at the same time people need a place to live, food and income that depends on the existence of the forest. Forests are no longer an asset to be exploited but also conserved. Environmental awareness emerged during MN VII, and was confirmed by the presence of a number of regulations regarding the management of the Mangkunegaran forest. This research is historical research. Then the method used is the method of historical research. The steps are four, heuristics or collection of sources, source critic, interpretation and final historiography or historical writing.
\end{abstract}

Keywords: Forestry Politics, Mangkunegara, Forest Management

\section{Introduction}

The management of the Mangkunegaran forest that is carried out professionally and structurally began at the time of MN IV, namely the establishment of the Kemantren Wreksa Pandaya [1]. Management of the Mangkunegaran forest under the kemantren Wreksa Pandaya is contained in Manuscript no. 12 (11 August 1867), concerning the division of the bureaucratic structure of the Mangkunegaran Duchy during the reign of Mangkunegara IV. More specifically it is explained in Chapter 8 which states that the bureaucracy which has the authority to deal with the provision of all palace needs is handled by Kawedanan Pura Baksana, in whose authority there are 3 kemantren, one of which is kemantren Wreksa Pandaya. There are 3 main tasks of kemantren Wreksa Pandaya, serving the demand for teakwood used for home needs and interior-decoration, knowing the size, location, and ease of the situation of the logging site, and maintaining teak forests, providing wood for cooking and making charcoal. In carrying out its duties the mantri Wreksa Pandaya is assisted by several Blandong (loggers).

An interesting fact emerges related to the position and direct authority of forest management. As stated in Manuscript no. 21, July 30,1871, which contains the regulations issued by Mangkunegara IV, concerning the management of teak trees and yearly trees in the Mangkunegaran region. In this regulation, the position of mantri wreksa has never been 
mentioned, but the ones who are more commonly referred to are the servants of the court of blandhong. Abdi-dalem Blandhong should control and maintain all of the king's teak forests. In carrying out his duties the servants of blandhong were assisted by several subordinates, from the rank of demang, rangga, clerk, mandor, to kajineman. Abdi-dalem blandhong gets the title Hoofsinder Eersteklaas (Blandhong class 1), here in after referred to as hoofsinder blandhong and his appointment of office is stated in piagem. This regulation gives a large authority to hoofsinder blandhong officials to manage the king's forest.

\section{Result and Discussion}

Entering the middle of the nineteenth century, the Mangkunegaran government experienced an economic down-turn, especially during the MN V administration [2]. Mangkunegaran's internal political conditions began to deteriorate in that period, and this affected the civil economy, one of which was a plantation business and a decline in production. The chaos of the government and financial mismanagement made Mangkunegara ignorant of former coffee gardens that were no longer productive.

The economic and government crisis during the MN V was caused by several things including, courtiers who were busy enriching themselves, the size of their debt, and unable to pay the salaries of employees and courtiers. Besides that, bad conditions also occur in plantation companies where there are attacks of coffee pests and sugar cane. The chaos caused the colonial government to feel the need to intervene in overseeing the economic activities of the community, with the appointment of a Superintendent. The external cause of the Mangkunegaran economic downturn mainly came from the fall in sugar prices due to sugar beet protection in European countries to limit the entry of sugar from Java.

Mangkunegaran's economic and financial downturn during the MN V period, was saved by MN VI by implementing supervision and tightening spending policies, such as cutting benefits for courtiers, separating bookkeeping and managing financial matters from companies, saving internal royal expenditures especially for celebrations - celebration and simplify the ceremonial procession in the palace. In terms of managing the MN VI company took several policies to closely monitor the company's financial flow (1899), strengthen the plantation industry, by repairing gardens that were still productive and planting crops that would certainly sell well in the market. Besides, the Mangkunegaran government also abolished the obligation to hand over coffee to Gubernement (1901) and closed down companies that had not provided benefits to the community. The business aims to get maximum profits to strengthen the cashier and set a reserve fund. In general, the economy has not recovered properly, but at least the princes managed to cover their debts.

Economic expansion, forest exploitation, and neglect of environmental conditions that occurred throughout the government period of MN IV, V until the beginning of MN VI, had a quite alarming impact, namely falling forest degradation and decreasing environmental quality. As stated in the colonial government's official report that Javanese ecology in the second half of the nineteenth century was characterized by deteriorating conditions in Javanese forests, reduced primary forest cover, the disappearance of endemic species, droughts, floods, and landslides as a result of widespread exploitation and decline and forest quality [3]. Caused by five things, first, the occurrence of abuse of authority carried out by officials who are in charge of forest management, from central officials to the regions. Second, timber theft is usually carried out by residents around the forest, and in some cases, this theft is known by the forest overseer, but left alone. Third, population growth has increased sharply requiring land as a place 
to live and a source of livelihood. Fourth, the degradation of teak forests in Java is usually caused by deforestation to obtain timber sortations for people's houses, merchant boats, and fishing boats. Fifth, demand for timber in the form of logs or logs on the world market, against Javanese forests.

\subsection{The emergence of Environmental Awareness in the Independence Period VII}

Environmental awareness at the time of MN VII can be seen in efforts to save the environment and governance. One of them is the realization of the reforestation plan, which was initiated during the MN V-VI. In collaboration with the Surakarta Sunanate and the Dutch East Indies government, establishing dams, urban drainage, parks, and urban forests. This is inseparable from the experience that occurred in Surakarta sometime before, namely the occurrence of droughts and floods.

To realize the policy of improving the environment and especially forest destruction, MN VII applied new forestry politics, namely the management of the Mangkunegaran forest under Wanamarta. Initially Wanamarta as a service that could contribute to increasing household income in the forestry sector. His main task is to manage forests in the Mangkunegaran region. Forest management includes maintenance, supervision, and utilization of forests.

\subsection{Period forest regulations MN VII}

Based on the results of the search, it was found that the three regulations of the Mangkunegaran municipality were related to forest management. These regulations can be explained as follows;

\section{Rijksblad Mangkoenagaran 1920 No. 22}

In 1920 the Mangkunegaran government issued a policy regarding the management of timber forests within its territory. This arrangement also provides a legal umbrella for the Mangkunegaran party, if it wants to utilize its forest assets for internal palace needs as well as trading commodities. Briefly, the regulation contains five main things, namely about, (1) confirmation that the ownership rights of teak forests are in the hands of the king. (2) concerning the granting of permits for the utilization of wood and parts of forest wood. (3) about the way that is permitted in the utilization of forest wood. (4) concerning the prohibition on timber extraction as well as the share of Mangkunegaran-owned timber and which (5) is about the prosecution of forestry violations.

\section{Rijksblad Mangkunegaran in 1923 no. 6, October 13, 1923.}

The regulation produced in 1923 was about the management of forests in the Mangkunegaran region, to distance crime, fire, and disaster. Prevention of the dangers of forest fires is mainly emphasized in April to December, given that during these months they are in the dry season. Rijksblad Mangkunegaraan 1923 No. 6 is the second forestry regulation issued officially by Praja, Javanese administration unit in vorstenlanden region, after three years from the previous regulations. This new regulation further emphasizes the ownership rights of forests and timber trees in the Mangkunegaran area as the property of the king, stating that none of the 
trees that grow in the Mangkunegaran forest have the status of dark wood. This regulation specifically mentions several areas in Wonogiri district that have forests and are claimed to belong to the king of Mangkunegara. It is reasonable to suppose that the Wonogiri region was recorded as an important asset for the Mangkunegaran community, through its forest wealth.

\section{Rijksblad Mangkunegaran in 1940 no. 3}

This regulation contains matters that regulate the classification of forests and forest types managed by the Mangkunegaran municipality, namely the base of teak and wooden bases of the year. This regulation also regulates the provision of land that is used as pedestal grounds or teak forest gardens. Besides, this regulation also regulates ways that can be carried out in the context of forest preservation and utilization, including the agency or person entitled to harvest forest products. The people living around the forest can also collect forest products if they have obtained permission from the competent authority over the forest in question.

Looking at the 3 regulations, it can be seen how the environmental awareness orientation of Mangkunegara VII. At Rijksblad Mangkunegaran year 1920 no. 22, in addition to the regulation acting as a legal umbrella for the government in utilizing its forest assets, it also indicates that the government is experiencing problems regarding forest ownership rights, thus requiring confirmation that the teak forests in the Mangkunegaran area are legitimately owned by the king. This can be understood because in general, the economic condition of the civil society has just risen from the downturn, where the management of forest status has been neglected. The government needs legitimacy to reaffirm the boundaries of its forest area. At the same time, the municipal government was also actively developing the city of Mangkunegaran so that it needed the support of natural resources obtained from its forests.

Rijksblad Mangkunegaran year 1923 no. 6 was born in an atmosphere of security stability that was not conducive, where crime rates, especially those related to forests, showed an increase. In several articles, it is stated that the municipal government must determine what weapons are allowed by the people if they enter the Mangkunegaran forest area. Other reports also provide information that municipal security conditions also experience disruptions such as theft, legality, and robbery, where the perpetrators usually escape to the forests after launching the action. Another crime related to the forest is the occurrence of illegal logging taken from the Mangkunegaran forests. Another problem faced by civilians is the climate constraints that have the potential to be the cause of forest fires, it is clearly stated in the regulation, where the government asks the public and local authorities to be aware of the potential for forest fires in the dry season, which at that time fell between April and December.

Mangkunegaran regency regulation, Rijksblad Mangkunegaran 1940 no. 3, more focused on efforts to seek several areas to be reserved as pejaten locations or teak forest gardens. This regulation also indicates that the community is beginning to carry out forest encroachment regularly, to be used as agricultural land and residential areas. As a precaution, at least there is a way taken by the government, namely with Karang Kitri and intercropping. Both programs demand the involvement of community members, especially those who live around the forest to prevent illegal forest encroachment. Karang Kitri seeks to use home gardens to be planted with timber trees, both teak, and timber, to meet household needs. Whereas tumpang sari is a community involvement program in indirect forest guarding. The way to do this is to allow the community around the forest to plant land around the forest and between trees with food crops and crops. This way is considered more effective in efforts to safeguard forests from looting timber and land, considering the government does not have enough funds to pay for forest security personnel. 


\section{Conclusion}

Management of the Mangkunegaran forest under the kemantren Wreksa Pandaya is contained in Manuscript no. 12 (11 August 1867), concerning the division of the bureaucratic structure of the Mangkunegaran Duchy during the reign of Mangkunegara IV. The exploitation of the Mangkunegara IV forest is like two knives for its prejudice, on the one hand it brings economic prosperity but on the other hand brings ecological damage. Mangkunegara VII makes several forestry regulations. These regulations generally limit the access of people living around the forest, to the Mangkunegaran forest. Problems then arise when at the same time people need a place to live, food and income that depends on the existence of the forest. Forests are no longer an asset to be exploited but also conserved. Environmental awareness emerged during MN VII and was confirmed by the presence of a number of regulations regarding the management of the Mangkunegaran forest. This research is historical research. Then the method used is the method of historical research. The steps are four, heuristics or collection of sources, source critic, interpretation and final historiography or historical writing.

\section{Acknowledgment}

This paper is a small part of my dissertation which discusses Mangkunegaran forestry politics. some parts of this paper are also discussed in a deeper context in several chapters from the dissertation that I am working on. This writing is due to the support and encouragement of my supervisor Prof. Bambang Purwanto and co-supervisor Dr. Pujo Semedi Hargo Juwono. For this reason, I feel deeply indebted and want to express my deepest gratitude and appreciation.

\section{References}

[1] Witasari, N. (2019, May). What Stories the Forests Tell You: Myths as Part of Forest Conservation Dynamics. In International Conference on Rural Studies in Asia (ICoRSIA 2018). Atlantis Press.

[2] Sudardi B, Hum M, Sukerta PM, Kar S, Si M. THE FALL OF MANGKUNEGARAN'S POLITICAL AND ECONOMIC AUTHORITIES. Journal of Education and Social Sciences. 2016;5(2):181-6.

[3] Smiet AC. Forest ecology on Java: conversion and usage in a historical perspective. 